\title{
The Yorùbá Social Values in Ọbasá's Poetry
}

\author{
Saudat Adebisi Olayide Hamzat \\ Department of Linguistics \& Nigerian Languages \\ University of llorin \\ Nigeria. \\ saudathamzat@yahoo.com or saudat@unilorin.edu.ng \\ Hezekiah Olufemi Adeosun \\ Department of Linguistics \& Nigerian Languages \\ University of Ilorin \\ Nigeria.
}

hezekiahadeosun@yahoo.com; hezekiah@unilorin.edu.ng

\begin{abstract}
Among the social values which equip the Yorùbá person are honesty, transparency, accountability, integrity, justice, fair-play, family sense, hard work, and truthfulness. The basic values of the people determine their behavior and what they direct their energy toward. Yorùbá social values have received serious attention from scholars. However, the ideology that inform the social values have not been given a deserved attention. The main aim of this essay is to investigate the Yorùbá social values in Ọbasảs poetry texts - Àwọn Akéwì I-III (1924, 1934, and 1945). The objective of the study is to examine the ideology which inform the social values, and which construct power. The paper also analyzes the extent to which the poet engages the ideology as exemplified in his poetry texts. In addition, the essay highlights the relevance of Obasás works to the contemporary Yorùbá society, and the literary devices employed by the poet to put across his message. The study employs descriptive and analytical methods using a New Historicism theory, which calls for a recovery of the ideology that gave birth to a text. The findings of this study reveal the Yorùbá philosophical thoughts on social values, and Obasás interrogation of the philosophical thoughts, which revere physical strength, wealth, position, children,
\end{abstract}


and knowledge as power. The study concludes that Obasá was a versatile and a thorough-bred poet whose poems call attention to the Yorùbá social values, to deconstruct and redefine power in a way that promote development. The study suggests that Obasás poems be studied holistically, and recommends that the poems should be reprinted and made available for scholarly work in institutions of learning.

\section{Introduction}

Society is a total complex of human relationship. Thomas \& Anderson (1977) posit that "the rules of the society are developed from the cultural values. The Cultural values are shared assumptions of what is right, good, or important" (53). These values come from the culture of the society. Thus, cultural values are different from one society to the other. The Yorùbá social values are entrenched in the concept of omolúäbi (a person of a good character). Omolúäbí connotes a man or woman who has been trained to behave properly, observing and putting into consideration the various shortcomings of others. The social values are used to guide their interrelationship.

The role of literature in analyzing the interrelationship between members of a society cannot be overemphasized. Literature is an imaginative and artistic representation of social and political experience in a given society. It is a fictional portrayal and an interpretation of the views widely held by the people. Whether oral or written, literature deals with all aspects of human activities in the society. All forms of literature have common intrinsic values of instruction, pleasure, and culture preservation. According to Ogúnsínà (2006), both oral and written literature function as a country's symbolic criticism of social values (42). Therefore, through literary works, power use and actions arising therein can be studied.

In the whole phase of literary development in Yorùbá scholarship, Obasa is acclaimed an early pioneer in the area of written poetry. He was among the early poets who Fálétí (2009) describes as poem recorders who wrote the Yorùbá traditional poetry in book form (3). Obasa achieved fame with his first collection of poems titled İwé Kínní Àwọn Akéwì published in 1927. This book was published at a time when the reading public wanted a diversion from oriki. Consequently, Obásás İwé Kínní Àwọn Akéwì readily became a best-seller. Its success was probably due to the fact that it had no irrelevances and so was produced cheaply (Fáléti 2009: 5). The success of the first book led to the second İwé Kejì Àwọn Akéwì in 1934. Obásás İwé Kẹta Àwọn Akéwì and Oríkì Oríle Àwọn Yorùbá were published posthumously in 1945.

Among the critical works on Obasá is that of Olábímtán (1975) which examines language and style in Ọbasás poetry. Olábímtán (1975) asserts that 
Obasá was a great Yorùbá poet in his own right, saying that "the three volumes of Yorùbá poetry produced by him between 1927 and 1945 had a great impact on the adults who were impressed by the wealth of traditional sayings (including chants and songs) in his poems, and also on the school children who were made to learn some of the poems by heart" (1031).

Even though Akínyẹlé had published in 1911 his own valuable book, İwé İtàn İbàdàn, İwó, İkírun àti Òșogbo which contained a lot of oríki, Lijadu had collected and published Ifá verses, and had helped to publish the poems of such poets as Aríbilóșòo and Șóbọ Aróbíodu in 1920, before Obasá, none of the earlier writers had made use of as many types of Yorùbá oral poetry in their works as Ọbasá. As rightly declared by Ọbasá himself in the "İjúbà" (prologue) to İwé Kínní Àwọn Akéwì:

Ó di ọdún mọkànlélọgbọn nísisìyí (AD 1896) tí mo ti bẹrẹ sí șaáyan kíkójọ àwọn ơrọ ogbọn àtaiyébáiyé ti àwọn baba nlá wa, tí i máa hàn jáde ninú orin, ègè, rárà, ijálá, ipẹsà, àròfo, oríki, ilù, fèrè àti àgbékà orọ wọn...

For the past thirty-one years (1896-1927) I have been assembling Yorùbá traditional sayings which embody the wisdom of our fore-fathers. These sayings are found in songs and in various forms of Yorùbá poetry; ègè, rárà, ìjálá, ìpẹsà, àròfọ, oríkì, and in the language of the drum and the flute. (Translation from Olábímtán, 1974b:1032).

Following this assertion, Olábímtán (1975) identifies Obasás greatness as a poet. He notes that "his poems are not mere assemblage of Yorùbá sayings, but a unique creation in his use of Yorùbá oral poetic language and style. He employed expertise to 'produce' written poetry at a time when many writers of Yorùbá poetry were much influenced by English poetic style" (1034). Obasá himself declares that he conveniently mediates between oral and written in İwé Kínní ti Àwọn Akéwì in his poem entitled "İkíni":

Ėmi l'Akòwé Akéwì,

Ėmi l'Akéwi Akòwé.

Bí mo tí nké kíké;

Bẹ na ni mo nkọ kíkọ,

Ėmi a sì máa tẹ l'ótite (Ọbasá1927: 2).

I am the poet's scribe,

I am the literate poet;

On the one hand, I write my own poems,

On the other hand, I help to reduce others' to writing. 
Furthermore, I am a printer. (Translation from Ọlábímtán, 1974b: 1033).

Ọlábímtán (1975) categorizes Ọbasás poems in to three. They are; 1) those which are strings of traditional sayings with little or no addition from Obasá; 2) those which have Obasás original composition joined to strings of traditional sayings; and 3) those which are Obasás original composition on selected, traditional sayings (1033). The study analyzes the poems as entity in which various forms of Yorùbá oral poetry; ègè, rárà, ìjálá, ìpẹsà, àròfọ, oríkì, and in the language of the drum and the flute intertwine.

Akínyẹmí (1987, 1989, and 2017) is another scholar who has worked extensively on Ọbasás poetry. Akínyẹmís 1987 unpublished M.A. degree thesis is established on two literary theories which are hermeneutics and structuralism. The study highlights the extent to which Obasá draws from the Yorùbá oral poetic materials in composing his poems, it suggests that when assessing Obasá as a poet, more emphasis should be placed not only on his use of Yorùbá oral poetic materials but also on his effective choice and combination of the selected oral poetic materials, the message, and the aesthetics of such composition. The study affirms that Obasá is very much concerned with the Yorùbá worldview. In his most recent work, Akínyẹmí (2017) discusses the social values, the Yorùbá worldview and philosophical thought enshrined in the folkloric material that formed the basis of Obasás poetry. According to him, one major issue given prominence in Obasás poetry is the value that the Yorùbá attach to children: "The child is presented in a number of Obasás poems as the axis around which the entire life of the Yorùbá rotates" (10).

Akínyẹmí (2017:10) also identifies the factors that shape Obasá as a poet and local intellectual. These factors are: (1) his membership of the socio-cultural group Egbẹ-Àgbà-ò-tán (Elders Still Exist Society) formed in Ibàdàn in 1909; (2) the establishment of İlare Printing Press; and (3) the publication of the weekly Yorùbá newspaper, The Yorùbá News. However, Akinyemi's work did not focus on how Obasa's exposure aids his interrogation of the cultural/ institutional practices and ideology that informed the Yorùbá social values in his poems. Also, Akínyẹmís work did not identify Obasás style in interrogating the ideology that attach power to children, wealth, religion, etc., as the factors that inform the social values. Thus, this study analyzes the ideology that informs Yorùbá social values and Opasá's commitment to cultural and ideological interrogation on which Yorùbá value system is based. The study is conducted within the ambit of New Historicism Theaory. 


\section{New Historicism Theory}

The proponents of New Historicism Theory include Foucault (1974, 1978, 1979, and 1980), Greenblatt (1980, 1985), Montrose (1989) and Althusser (2012) among others. New Historicism is particularly influenced by Foucault's investigation of the workings of institutions and discursive practices. Adéyemí \& Hamzat (2014) and Hamzat (2016) advanced on these scholars' works. The New Historicism Theory holds that all interactions, whether in the public/political domain, or private/social arena, involve the use of power. Power is the ability to control others and particularly to control their thoughts. Individuals and groups who are privileged by virtue of their birth, knowledge, wealth, and strength exercise rights, privileges, and responsibilities. They control, dominate, and oppress others. This creates fear and enmity between groups and individuals. This is made possible through ideology. Ideology is the set of established values held by a social group.

Beliefs and institutional practices that are prevalent in an environment raise the consciousness of the people and are developed into ideology. It could be in form of political programs or manifesto, philosophical orientations, or religious codification. The control may be as minor as constructions or discourse that is used to control, manipulate, or influence the ways people think or see issues. To the New Historicism Theory, religion is an apparatus of power, which constructs, legitimizes and circulates beliefs about received and acquired knowledge. It legitimizes and circulates beliefs about other powers.

The New Historicism Theory sees ideology as a self-regulatory system of thought that sustains other forms of powers such as religious beliefs, and all forms of power. New Historicism favors interrogation of ideologies to redirect society's attention to the powers we submit to. It calls for the society to have a rethink about powers we submit to in the society, be it in physical, political, economic or spiritual forms.

Literature serves as a pedestal for the study of how ideology and institutional practices are constructed and, how power is generated and exercised. How Obasá engages in cultural and ideological interrogation in the poems under examination and redirect society's attention to the powers attached to physical strength, knowledge, children and wealth is our concern in this study. The study redirects society's attention to the powers attached to physical strength, knowledge, children, and wealth through Ọbasás poetry.

\section{Analysis}

To Obasá, knowledge is power. Adéyemí \& Hamzat (2014) as well as Hamzat (2016) identify the role of religion in instituting all kinds of power. The religious leaders are supposed to offer guidance and direction to the people, 
but they misuse the power at times. Obasá gives his impression of the Islamic priest in the poem, "Onimole" that feeds fat on his followers:

Bisimilai, Lau; Lau

Lo' difá fun 'Mòle

Abèwù gèrè

To faye gbogbo sefe

Bisi ki ilà lásán,

Bíkò bálayán

A la'kà, a là 'ko

A la 'bi, a làmolà (Obasa 1934: 9).

Bisimilai, Lau, Lau

Divined for an Islamist

Who is dressed in a loin-cloth

Who feeds on others

He does not recite the Quranic verse for free

If he does not take pounded yam

He takes cooked yam flour paste, he takes pap

He takes kolanut, he takes cooked yam flour paste.

In the above excerpt, Obasá plays on the syllable la to depict the array of food sharing that the privileged leader enjoys. Obasá redirects attention to how religious providence gives the religious leaders power to hoodwink their ignorant and innocent followers.

In "Ògbifơ Kéwú Ìbàdàn," Obasá portrays how the Islamic priest uses his knowledge of the Arabic language to subjugate and oppress those who do not understand the language of the Quran. The Quran verse used to open the poem is:

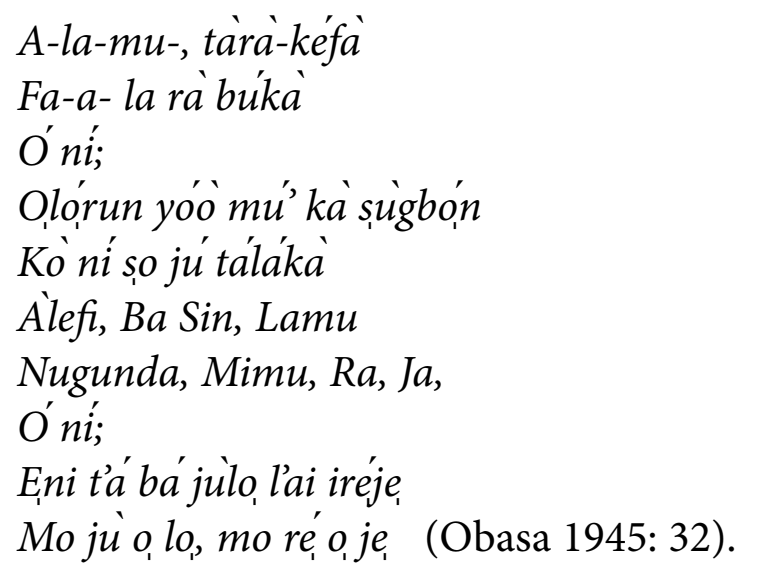


A-la-mu-tàrà-kéfà

Fa-a- la rà búkà

He says;

God will arrest the wicked but

It will not be in the presence of the poor

Àlefi, Ba Sin, Lamu

Nugunda, Mimu, Ra, Ja,

He says;

It is one we have power over that we oppress

I am your superior, I oppress you.

Obasá uses wordplay to give his own interpretation of the verse. He laments that God will catch up with the wicked but it may not be in the presence of the ignorant masses. He coins ikà (the wicked) from the syllable $k \dot{a}$.

In the same vein, Obasá refers to the Ifá priest who demands sacrifice from clients as oppressors. He satirizes the religious leaders who are forbidden to demand for big animals, they are restricted to goat and chickens. The restriction to pet animals put a limitation on their power.

Ewưré inú ilé

Un Lơrúnmilà ise gbá-keke-gbá-keke, mó

A'gbébò adie toun teyin

Un Lòpèlè ile bo móle

Lórúnmilà le bo móle

Etu, àgbonrín, Èsúro,...

Nown rékojá êran Ifá (Obasa 1945: 33).

A goat residing in the house

Is the one Orunmila has a domineering power over

A chicken with its eggs

Are materials divining cord is capable of over-powering

That can also be over-powered by Orunmila

Antelope, deer, roe-buck

Cannot be used as sacrifice for Ifa

The Ifa (Orunmila) priest is not likely to sacrifice wild animals like lion, tiger, and hyena. Sàngo's power over all trees in the forest does not extend to timber. The Yorubá proverb b'i sàngó ń pàràbà, tí ń fàrókò ya, bíi tigi ńlá kó, (Even if Sàngó has the capability to destroy the iróko tree, he does not have power over the big tree) supports this line of thinking. 
Onísàngó mogi en

Óun 'o gbon dà sí (Obasa 1945: 33).

Sàngo priest knows the tree

He can sharpen his cutlass for

The Yorùbá people put value on wisdom, knowledge, and smartness but frowns at using one's knowledge or expertise to cheat others. Some people think they are intelligent, and thus cheat in business dealings. The ideology about wisdom is expressed in two poems: "Ogbón" (Obasa 1927: 60) and "Äigbón" (Obasa 1934: 14). The ploy of deceit is exemplified in the pap-seller whose pap is too small. The buyer who measures the sizes of the pap and drops it without buying is smarter: adáko kére ko gbón bí asówo má rà (the pap seller who reduces the size of the pap is not as smart as the one who measures the sizes of the pap and ends up not buying [41]).

The Yoruba value and appreciate beauty and elegance as factors that give those who are blessed to have them, power. They paint the picture of the peacock as the king of birds. They see women as symbol of beauty and elegance. However, women who are too conscious of their beauty, and allow themselves to be intoxicated by their beauty are warned in the metaphor of a peacock in the poem "Agánnigàn II" where Òkín, the bird of beauty and elegance is used to represent women who allow themselves to be intoxicated by their beauty.

\author{
Agonnigòn obinrin \\ Ti i gboko, lowo olóko, \\ Singìn níbi... \\ Amo-o-din-mo-o-se iya Olobe \\ s'epon kanrin; \\ O fob be, gbo ko lowo olóko. \\ O gbode tan..... \\ O se bi ire, bi ire \\ O gba'le lowo olóko, \\ Agonnigon obinrin \\ Ni i fi kerewu b'apa \\ Apapa toro-pa, \\ Inu re ko duro gbomo, \\ Ki igbomo, re ipon \\ Bikose lagidigba; \\ Omo, su si Jojo \\ Inu okin baje
}


Omo su si Jamo inu mboge

Eleyinju ege.

........

A ri ma le lo, a kò pada sehin

A ko pada sehin;

Rora, Agonnigon, rora...

B'a ti jaye to,

Beę l'ayeșe e je ni (Obasa 1934: 7-8).

A wild/nagging woman

Who snatches another woman's husband

Singin nibi...

Who specializes in preparing delicious food

Cooks to the extreme

Who snatches another woman's husband

Having taken over the lobby/hall/anteroom

Gradually

She takes over another woman's home

A wild/nagging woman

With unique beatification

Physique that is unique

Her womb cannot contain a child

She does not back a real child

But waist beads

Baby messes up her clothe

The peacock becomes sad

Baby messes up her clothe, beauty is angered

Elegant lady

Who no man sees and resists

Who catches every man's interest

Be careful, the wild one, be careful...

As one revels or enjoys life

So does life entrap one

Obasá cautions that beauty intoxicates, and warns women who are too conscious of their beauty to be cautious, as the society that admires them will turn around to vilify them. The society, for no just cause, associates bareness of women to the loose life they lived during their youth. Obasa puts this across by using derogatory adjectives like agonnigon for such an elegant lady. 
Hamzat (2016) has argued that children are symbol of power among the Yorùbá. This informs their quest for children, and the lack of it is the reason for anxiety in the life of any Yorùbá man. The importance attached to child-bearing is expressed in the following Yorubá popular sayings omo lèrè ojàlayé (The reward of coming to the world/existence is child bearing), omo lèrè ìgbeyàwó (The reward of marriage is child bearing), orí jómo ó sin wa (may our inner head make it possible for our children to survive us after our death). Another Yoruba poet, J.F. Odúnjo also underscores the importance of children in one of his poems. The lines go thus:

\section{Omonigbèyìn olà}

Omo lará, Omolèye ...

Omo ni yóo jogún ewà léyín wa (Odunjo 1960: 5).

Children are end product of wealth

Children are relations, Children are joy

Children will inherit our beauty

The Yoruba equate children with priceless gems in the following sayings omo òmó osin, omo niyùn, omo nide, kò si láte, olówó kò rì í ra, olómo ló layé, omo, bori owó (O child, a gift of the osin, the valuable coral bead, the bronze, not a commodity displayed for sale that the rich can purchase. He who has children owns the world, a child is superior to wealth). As a result of this, the quest for children to sustain one's lineage becomes serious. In this type of setting, childlessness is seen as a curse. To have children is to have power. This belief makes children a form of power to those who have them. The idea is to replicate oneself for the continuity of one's lineage. Obasá engages in interrogation of this quest. He stresses that although children are source of power in the society, they may not have such power when they are ill-equipped.

Obasa commits his poem to proper upbringing of the children in "Àkéju" when he says omo, taa kó ni ó gbélé táa kó, tà (a child not well trained will put up the house we built for sale). Also, in "Ä̈gbón", the poet begs for nurturing of children:

Dindinrin kì i bá won lágbà

Omo tí ò gbón nílé kì í mòran lóde (Obasa 1934: 14).

Stupidity does not manifest at old age

A child who lacks wisdom from home will not be knowledgeable outside 
The Yorubá moral ideology design to warn the society on proper upbringing of chidden into proper omoluabí (a person of a good character) is exemplified in "Aläigbòràn" (Obasa 1927: 15-16).

The quest for children is the reason for anxiety in the life of every Yorùbá man, worst still is the quest for wealth that one will bequeath to one's unborn generation. The manner in which some highly placed people in the current political setup amass wealth for their children with no sense of decorum is alarming, and could be counterproductive. People amass wealth for their future generation without knowledge of who will outlive them (Obasá 1927: 11). In Obasá's view, preference should be on the child upbringing rather than on wealth accumulation for inheritance.

Wealth defines status in human society, and wealth is defined in terms of money. Thus, Obásá (1945) demonstrates the power attached to wealth in his poems, "Olówo" and "Owó-Ajé" (9). He eulogizes the power of wealth, by alluding to different names given to money (aje, osin) in Yorùbá society. These names reiterate the importance of money in:

Ajé ògúngúnisó

Osin, ormo a'-sebi-d-àre...

Ajé náa ní í so osán dòru (Obasa 45: 9).

Money, the mighty

Osin, offspring that turns guilty into acquitted

Money indeed turns daylight into midnight

He also emphasizes the evil attached to money through naming, he calls it oówo,(the boil) and ottè (conspiracy) in:

Oówo tó sòmòràn lónà ơfun

Owó ní í jẹ́báun...

Òtè ní í sojú ơmoluáabi di terranko (Obasa 1945: 9-10).

The boil that afflicts the knowledgeable man in the throat

Those are the names that money bears...

Conspiracy that turns a humane person to behave like an animal

The power of wealth is put across in naming, personification, and praise poetry. Obasa paints the evil picture of money thus:

Kò si óhun tólówó kò le ro

Olówó ní í somi ìwè

Domi àmalà 
Ohun tówó bá pa tí kò kú

'Un le pé kálu lógo?...

Olówó n' sòrò enu rè n' laná;...

Ibi tó bá wếfúifulètlè ní $i$ dari

Ní í darí ìgbé sí;

Ibi tó bá wolówó ẹni ní í rán ni lo (Obasa 1945: 11).

There is hardly anything a rich person can't think of

The rich turns the bathe water

In to water for preparing cooked yam flour paste

Whatever money kills and does not die

Is what is asked to be hit by rod

The rich is talking with fire coming out from his mouth

Wherever pleases the wind

It directs the bush leaves

Wherever pleases one's lord he sends one

The power the Yorùbá attached with money is intoxicating as the language of the poem reveals. Money turns guilty into acquit, turns daylight into midnight, and it is the boil that muffles the knowledgeable man in the throat, as he will tell lies when tempted with money. In Nigeria society, learned men and women have been so disgraced. The situation is so bad that the society discountenances the opinion of elders with wisdom and experience if s/he has no money. The Yorùbá believe that money is the source of all evils.

The poet reveals that there is the likelihood for the rich to be arrogant, boastful, corrupt, and therefore oppress the less privileged members of the society, who with envy and betrayal, agitation and conflict may accompany these traits. He therefore begs for caution on the part of the rich, and warns anybody exhorting on account of wealth that destruction will follow arrogance:

Èmi mo lowó mi ni,

Ní í bowó omodé jé (Obasa 1945: 9).

I'm the owner of my money

destroys the wealth of a younger one.

Obasá demythologizes the power of wealth by revealing that there is a limitation on power wielding a rich person with an illustration of the Yorùbá pawning system in which the rich is forbidden from oppressing his pawn iwofá. A pawned individual stays indoors and reclines in bed like his master during an early morning rain downpour: bolówó gelete ì iwojà náa a si gelete 
- a wealthy man cannot send out his serfs in to the rain as he will send a slave - (Obasa 1945: 10).

Obasá, in "İfét Ėte" and "İferàn", queries why people scramble for power and wealth as the two can be counterproductive. If one is wealthy, friends and family will flock around him or her, and they flock away if there is a turn down in that person's fortune.
İgbà tí mo toșì
Kò séni tó mơ mí
Mo dolówó tan
Gbogbo won n'kími ní baba
Àwon a-rí-ire-báni-je.
Àgbòn isalè
Bá a bá kú lówúrò
A yà lálé (Obasa 1934: 4).
When I was poor
Nobody knew me
As I'm now rich
Everyone is hailing me
The fair weather people
If one's dies in the morning
He departs in the evening

To Obasá, human beings exercise power over each other. Individuals and groups that are blessed with physical and martial power are supposed to profit others. Animals that possess physical strength or might are used to illustrate oppressive power as it obtains in the folktale tradition. The size of the elephant, as well as the strength of the tiger and the lion are metaphorically used to depict human power over each other. Obasá in the poem "Ėte," illustrates the physical power that hawks have over chicks - It smartly hunts down the chicks on the dung hill:

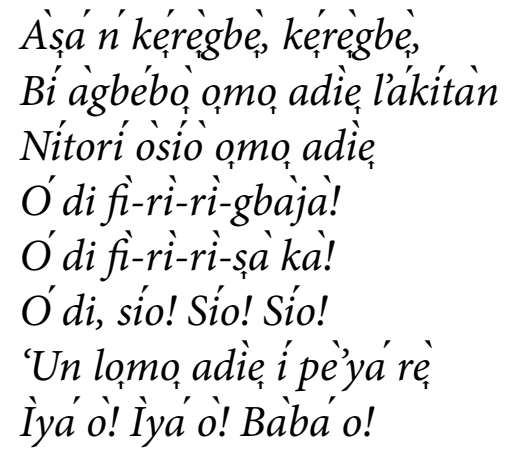


ó di, kù-rú-üu...!

Awó ti lo!!!! (Ọasá 1927: 15-16).

Hawk is walking slowly

Like the chick on the dung hill

Because of the chick

Suddenly

Unexpectedly!

The chick cries for help

That the chick beckons at its mother

Mother! Mother! Mother!

Before the mother knew what was happening

The hawk has flown away!!!

Man, represented by butcher has power over the goat, termites have power over anything, be it wood, clothes or paper. The rat is strong and agile in hunting and feeding spree all over the house. In the same vein, man and animals dread the power of the snake's venom.

Strong animals devour weaker animals for survival. However, some weak animals defy the destructive or oppressive power of the strong animals. At that time, their power is useless. So, they should exult less on account of their might. The hawk that hunts down the fast chicken cannot use this power over snail, even though the snail is slower: àwòdi wogbin korò (42) - Falcon glares at the snail. Termites' destructive power cannot be exercised on stones and rocks. The poem expresses this with the proverb:

Àbá lásán ni ikán n' dá, kò le mòkúta

À-tà-tà-n-kúra!

Enu eye kò le ran okúta

Apá èkuté le ko káwùsá, Níbi yíyí kiri ló mo (Opbasá 1927: 43).

It's only a wish, termites have no power to devour the rock.

It's an effort in futility!

Birds cannot devour the stone

The rat cannot over power the walnut,

it can only roll/toss the wall nut around on

the ground

The wall nut that stays in a spot defies the rat's power. In the same vein, human being cannot kill toad/frog to prepare the melon soup: 
Òpòló rì fanda,

Lójú elégusí,

Elégusi ko gbodo yí i l'áta. (Obasá 1927: 44).

The toad walks freely

In the presence of one skilled in the act of cooking melon

The melon soup expert cannot use it to prepare a stew

Representation of the physical, economic, and political power of man is done in animal metaphor in Yorùbá folktale. The size of the elephant, speed and strength of the lion are used negatively to depict oppression of the weak masses by the rich, and powerful rulers.

Knowledge and skill are associated with other animals like the tortoise, birds and ants. This often makes up for the smallness and weakness of such animals. In Obasás opinion, powerful men may fall prey to weaker beings just as the weak powerless tortoise often outsmarts the powerful elephant. Obasa makes an allusion to the power relation between the lion and the dog in the poem "Tanimènin." The lion is cautioned not to be too confident as the dog can turn around to outlive the powerful lion, and even use the lion skin as his sleeping material.

Òni la rí

Ojơờla ko yé ni...

İgbèyin ayé kò ju mo

Awo exi ti ko tí i kú

Eyin kò șe, Eyin kò sunwon

Ajá mawo êkun tésùn (Obasa 1934: 3).

We only witness today

One is not sure of tomorrow

No one knows the end of the world

One who is yet to die

The end is unpleasant

The dog sleeps on the lion's skin

To Obasá, power has its limitations. He successfully puts the message across by exposing the limitations of power associated with some animals. For example, man cannot devour toad, termite cannot devour stone, and the hawk cannot devour the weak sluggish snail. The tortoise is also useless to the snake in the face of hunger (ebi n pejo ahun $n$ yan - the tortoise moves in majestic 
strides in the presence of a hungry snake). This is so because its poisonous venom is useless to the weak and sluggish tortoise protected by its scale.

Hunger, as presented in the poem "Ebi", has control over all powers. However strong anyone may be, no one has control over hunger. The poem reveals that no matter how knowledgeable one may be, one is powerless in the face of hunger. Obasá compares hunger with death, and concludes thus:

Eni ebi n' pa ki íkèèwò

Eni ebi n' pa ko kokú

B'ikúbá tikun,

Ebi ni i și i

Eni ikún pa kò tó nnikan,

Gbogbo ayé lebi n'pa. (Obasa 1927: 73).

One who is hungry does not respect taboos

One who is hungry fears no death

If the death closes the door

It is hunger that opens it

Limited number of people are being killed by death

All people over the world feel the pang of hunger

The poem shows that any hungry person will break rules and laws guiding social values in the society. Aberration will happen in the face of hunger. Hunger and death are no respecters of people, no matter their power. There is no medicine or ritual against death (Obasa 1927:76).

Political power is another form of power that is used to oppress. People in quest of political power are called to order in the poem "Onijongbon" (Obasa 1945: 11-13). In Obasá's view, everybody desires power without considering the hardship that accompanies it. He uses the parable of the mortar and pestle to explain the problem associated with power. The Mortar struggles to the throne of the imaginary city of İgunyán despite warnings that he should not aspire to such a position. The result is the busy and strenuous exercise that the mortar is subjected to. It is constantly moved about by women, old and young to pound fresh and dried yam, pepper, herbs, and corn.

Kìtikiti- kitikiti

Òdòde İódó

Odólóun ó jọba

Nílu İgúnyán...

Odó joba joba tán

Odó kò ráyè sinmi mo. 
Bá ò ródó

A kole gúnyán

Bá ò ródó

Obìnrin ko gógi...

Y'do' wa', yi'do wa

Aata n' todó lojú

Aata n' todo' n'imú

Aata n' todó l'ènu...

Nwon gódo' titi-tí

Odó sán létí

Odódálu, Odó ya... (Obasa 1945: 11).

Struggling upward-downward

It lands in Igodo's compound

The mortal says he wishes to be crowned a king

In the city of Igunyan

The mortal succeeded being crowned a king

Thereafter, he has no peace of mind anymore

Without the mortal

Women cannot pound yam

Without mortal

Women cannot pound pap

Mortal's moving up and down

Pepper is peppering the mortal in the eyes

Pepper is peppering the mortal in the nose

Pepper is peppering the mortal in the mouth

The mortal is pounded

Till it cracks

The mortal is completely destroyed

Obasá employs personification to paint a picture of how the once strong mortar degenerates in physical strength like a human being. Thus, any one in quest of power is warned to be cautious. If human is conscious of these limitations, s/he will heed the warning of Foucault (1974) that power is not synonymous with oppression. He / She will boast less, knowing that pride precedes fall, and care more for the welfare of others. Negative use of power can only breed jealousy, envy and betrayal, agitation and conflict. This is what happens in the animal metaphors that Obasa employed in one of his poems in which chickens are reveled as rejoicing at the demise of members of hawk's family. In the same way, the goat dreams of the butcher's death: 
Kơlòkòi lò ibá kú,

Adiè ko sunkún,

Ewúré walápatà,

Bíkó kú, bí kó kú,... (Obasá 1927: 42).

\section{A fox's death}

Will not call for hen's mourning

The thought of the goat to a butcher

Is that of death

The Yorùbá attach value to the welfare of individuals and groups. Obasá calls attention to values as little as greetings in "İkíni" (Obasá 1927: 62) as an agency for securing peace and harmony. Enquiries are made about the physical, psychological, and economic welfare of people being greeted, and it is an honor that should be reciprocated. In the contemporary period, new development reveals that the era of being one's brother's keeper has gone, insensitivity to each other's plight reigns. The Yorùbá social value of caring for and sharing with others is being ignored nowadays. The snail family is used to illustrate this in the poem entitled "Ayé Òdajú" (Otbasá 1927: 62). In the poem, the whole lot of snail family; ipere, iláko and isawuru are being swept away by flood, and yet all claim not to know. Human beings should be concerned about the quality of life of others in Obasás view.

\section{Conclusion}

This study has examined the Yorùbá ideology about power, and shows that ideology informs views expressed in the society on social values. The findings reveal that the Yoruba's ideology about power dictates their views about life. Obasás poetry texts contain intellectual and philosophical construct, explaining social conditions and beliefs about life in the Yoruba society. His poems reveal that power has nothing to do with birth or wealth, physical strength or might, beauty and elegance. Power is achieved through wisdom and skill. Obasa, in line with Foucault's (1974) call engages in cultural and ideological interrogation in the poems under examination to prove that power is not synonymous with oppression. In Foucault's view, power is an action exercised for the good of the people.

The essay concludes that Obasá was a versatile and a thorough-bred Yorùbá poet whose poems call attention to the Yorùbá social values, deconstruct and redefine power in a way that engender or promote development. Obasa's interrogation of the ideological values in poetic language reveals that he conceptualizes power in physical, economic, as well as in socio- political terms. 
He, however, notes that power is not measured by any of these but by concern about the quality of life of others. The essay suggests that Obasás poems be studied holistically, and recommends that the poems should be reprinted and made available for additional critical assessment.

\section{References}

Adéossun, H. O. "A socio-semiotic Study of Selected Yorubá Written Poetry." Unpublished Doctoral Thesis, University of Ilorin, 2012.

Adéyemí, L. \& S.A.O. Hamzat. "A New Historicist Analysis of Power and Politics in the Works of two Yorubá Playwrights. Yorübá: Journal of Yorùbá Studies. 7.3, (2014): 130-167.

Akínyẹmí, A. "Dénrelé Adéètìmíkàn Ọbasá (1927-1945) - Akéwì Aláròjinlè." Unpublished M. A. Dissertation, Department of African Languages and Literatures, University of Ife, 1987.

Akínyẹmí, A. “Ākóónú Ewì Àpilẹkọ Ọbasá." In Sola Adebajo (ed.). Sẹminá ní irántí J.S.A. Odujinrin. 100-121. Lagos: Odujinrin Publishing Company, 1989.

Akínyẹmí, A. "D.A. Obasá (1879-1945): a Yorùbá Poet, Culture Activist and Local Intellectual in Colonial Nigeria." Africa. 57.1, (2017): 1-15.

Atemie, J.D. \& B.K. Girigiri. "The concept of Culture." In M.O.C. Anikpo, \& J.D. Atemie (eds.),Nigerian Socio-cultural Heritage. 1-13. Port Harcourt: Amethyst \& colleagues, 2006.

Daniel, G. "A Foreword on Ọọlúàbí: Its Concept and Education in Yorùbá land." In A. Ogundeji, \& A. Akangbe. Ibadan: Ibadan Cultural Studies Group, 2009.

Fálétí, A. "Yorùbá Poets Past and Present: The Poem Recorders." Yorùbá: Journal of the Yorùbá Studies Association of Nigeria. 6.3, (2009): 2-10.

Hamzat S. A. O. "A New Historicist Analysis of the Selected Plays of Láwuyi Ògúnníran and Olú Owólabí." Unpublished Doctoral Thesis, University of Ilorin, Ilorin, Nigeria, 2016.

Isola, A. "Yorùbá Culture in Education." In A. Ogundeji, \& A. Akangbe (eds.), Omọlúàbi: Its Concept and Education in Yorùbá land. 89-112. Ibadan: Ibadan Cultural Studies Group, 2009.

Jaworski, A. \& N. Coupland. Sociolinguistics: A Reader Course Book. London. Palgrave, 1999.

Ọbasá, D.A. İwé Kiíní Ti Àwọn Akéwì. İbàdàn: İlàré Press, 1927.

Ọbasá, D.A. İwé Kejì Ti Àwọn Akéwì. İbàdàn: İlàré Press, 1934.

Obasá, D.A. İwé Keta Ti Àwọn Akéwì. İbàdàn: İlàré Press, 1945.

Olábímtán, E. A. “A Critical Study of Yorùbá Written Poetry, 1848-1948." Unpublished Doctoral Thesis, University of Lagos, 1974. 
Ọlábímtán, A. "Language and Style in Ọbasa’s Poetry." In W. Abimbola (ed.), Yoruba Oral Tradition: Poetry in Music, Dance and Drama. 1031-1069. IleIfe: Department of African Languages and Literatures, University of Ife, 1975.

Thomas, W. L. \& R.J. Anderson. Sociology: The Study of Human Relationships. New York: Harcourt Brace Jonanovich, 1977. 